\title{
SYNCHRONOUS SPORULATION OF SACCHAROMYCES CEREVISIAE AT HIGH CELL CONCENTRATIONS
}

\author{
by \\ JENS G. LITSKE PETERSEN \\ Department of Physiology, Carlsberg Laboratory, \\ Gamle Carlsberg Vej 10, DK-2500 Copenhagen Valby \\ LAURITZ W. OLSON \\ Institute of Genetics, University of Copenhagen, \\ $\emptyset$ ster Farimagsgade 2 A, DK-1353 Copenhagen K, Denmark \\ and
}

DENISE ZICKLER

Faculté des Sciences, Laboratoire de Génétique, Bât. 400, F-91405 Orsay, France

Keywords: Yeast, meiosis, Feulgen

\begin{abstract}
A procedure for the sporulation of yeast is described which combines good synchrony and high cell concentration, important features in biochemical studies of meiosis. Meiosis and ascospore formation were followed by a modified Feulgen staining procedure, which allowed the detection of chromosomes during meiotic prophase. The sporulation process was also characterized with respect to nucleic acid synthesis, commitment to meiosis, and the segregation of the mutant and wild type alleles at the ade 2 locus.
\end{abstract}

\section{INTRODUCTION}

Cultures of certain strains of Saccharomyces cerevisiae can be induced to undergo synchronous meiosis and ascospore formation (2, $5,7,17,20)$. Such synchronization procedures have proven useful in studies of the meiotic process (for recent reviews, see 8, 22). Meiosis is induced when a diploid cell culture, preadap- ted to respiration, is transferred to nitrogen limiting conditions in a potassium acetate medium. In the important studies of CROES (2, 3), adaptation to respiration was obtained by growing cells to the end of exponential growth phase in a complete medium with glucose as the carbon source. ROTH and HALVORSON (17) improved the synchrony of sporulation by 
employing exponential cells pregrown in a potassium acetate medium.

The efficiency of sporulation is dependent on cell density (cf. 6). Sporulation in both systems is usually performed at cell concentrations of 1$3 \times 10^{7}$ cells $\cdot \mathrm{ml}^{-1}$. Although this is sufficient for genetical and cytological studies, it would be advantageous to have a higher cell concentration for many types of biochemical studies of yeast meiosis.

In the following we describe a procedure for the synchronization of sporulation of a diploid yeast strain at a cell density of $2.5 \times 10^{8}$ cells $\cdot \mathrm{ml}^{-1}$, i.e. a concentration 10-20 times higher than usually employed. In a recent study on protein synthesis during sporulation (14) advantage of the high cell concentration has been taken. The procedure has also been used in an ultrastructural study of yeast meiosis (23). The sporulation process was characterized as to the appearance of commitment to meiosis, segregation of a recessive marker, and the synthesis of DNA and RNA. Furthermore, a modified Feulgen staining procedure was developed which allowed a characterization of sporulation with respect to chromosome individualization at meiotic prophase, and other nuclear events.

\section{MATERIALS AND METHODS}

\subsection{Strain}

The diploid strain 11D of Saccharomyces cerevisiae, used in this study, was a particularly well sporulating segregant found in a stock of the tetraploid strain 11 (a/a/a/a ade $2 /+1+1+$ ade $6 /$ ade $6 /+1+$ his $8 /$ his $8 /+1+$ leul $/+1+1+$ lys $7 /$ lys $7 /+1+$ trp $5 /+1+/+$ ) kindly provided by J. FRIIS, Institute of Molecular Biology, University of Odense, Denmark.

The diploid state of strain 11D was inferred from tetrad analysis which showed disomy for 6 markers (genotype: a/a ade2/+ ade6/+ his $8 /+$ $l e u l /+l y s 7 /+)$ (T. NiLSSON-TILLGREN, personal communication). In addition, the strain seemed to be heterozygous for a recessive lethal, as only two spores in each ascus would germinate.

\subsection{Media and maintenance of cultures}

Presporulation medium (10): $0.8 \%$ Bacto yeast extract, $0.3 \%$ Bacto peptone, $10 \%$ glucose, $\mathrm{pH} 6.5$.

Sporulation medium (SPO medium) (10): 1\% potassium acetate, $0.1 \%$ Bacto yeast extract, $0.05 \%$ glucose, $\mathrm{pH} 6.5$.

YPD agar: 1\% Bacto yeast extract, 2\% Bacto peptone, $2 \%$ glucose, $2 \%$ Bacto agar.

All percentages are expressed in $w / v$.

The yeast was maintained on YPD agar at $2^{\circ} \mathrm{C}$.

\subsection{Synchronization of meiosis and sporulation}

Liquid vegetative presporulation cultures were started from a single colony inoculum at a cell density of $10^{2}-10^{3}$ cells $\cdot \mathrm{ml}^{-1}$. The culture was grown at $25^{\circ} \mathrm{C}$ in a water bath with aeration (approximately $100 \mathrm{ml}$ of sterile, humidified air per min). Bubbler tubes were constructed after the design of SNustaD and Dean (21). Ten ml of presporulation medium was normally used, however for larger volumes, $5 \times 22 \mathrm{~cm}$ bubbler tubes were constructed in which up to $150 \mathrm{ml}$ of culture could be grown. After 40-54 h of growth, a stage in stationary phase was reached at which at least $99 \%$ of the cells were unbudded. The cells were harvested by centrifugation, washed once with aerated sporulation medium (SPO) $\left(25^{\circ} \mathrm{C}\right.$ ), and pelleted by centrifugation followed by resuspension in SPO medium to a final cell density of $2.5 \times 10^{8}$ cells $\cdot \mathrm{ml}^{-1}$. Meiosis and sporulation was carried out at $25^{\circ} \mathrm{C}$ with aeration. The start of an experiment, time $0 \mathrm{~h}$, was taken as the time when the cells were washed in sporulation medium. All cell concentrations were determined from haemocytometer counts of 300-500 cells.

\subsection{Determination of the meiotic stage by Feulgen staining}

The following Feulgen staining technique, based on the procedure by BRYANT and HowaRD (1), was found to stain intensely the chromatin of vegetative and sporulating cells of various strains of Saccharomyces cerevisiae. 
At intervals, samples of $0.1 \mathrm{ml}$ were taken from the sporulating culture and fixed in half strength Schaudinn's fixative after the technique of OLSON and FULLER (13). Half strength Schaudinn's fixative is composed of 2 vol. of an aqueous saturated mercuric chloride solution, 1 vol. of $96 \%$ ethanol, and 3 vol. of distilled water. Just before use 0.1 vol. of glacial acetic acid was added. The fixative was prepared fresh daily. The cells were fixed for $30 \mathrm{~min}$, pelleted by centrifugation, and washed once in distilled water. They were then resuspended in dilute egg albumin (E. Merck), spread on glass slides, and allowed to dry. The slides were placed in $5 \mathrm{~N}$ hydrochloric acid for $30 \mathrm{~min}$ at $23^{\circ} \mathrm{C}$. After hydrolysis the slides were washed once in distilled water, and stained for $2 \mathrm{~h}$ in FeulgenSchiff's reagent. Schiff's reagent was prepared with p-Rosaniline hydrochloride (Allied Chemical) rather than basic fuchsin, as the former was found to give a greater staining intensity. The staining solution is composed of 2.0 g p-Rosaniline hydrochloride, $3.8 \mathrm{~g}$ potassium metabisulfite, and $200 \mathrm{ml}$ of $0.15 \mathrm{~N}$ hydrochloric acid. The solution is shaken and stored in darkness for $2 \mathrm{~h}$. Then $2 \mathrm{~g}$ of powdered active charcoal is added, the solution is shaken for 30 seconds, and filtered. Glassware, funnel and filter paper were rinsed in $0.15 \mathrm{~N}$ hydrochloric acid prior to use. The staining intensity of the Schiff's reagent was further increased by adjusting the $\mathrm{pH}$ to 2.4 with $1.0 \mathrm{~N}$ potassium hydroxide just before use. The slides were rapidly washed in eight changes of distilled water to remove excess reagent. The colour was developed by washing in running tap water for $20 \mathrm{~min}$. The slides were dehydrated in a graded ethanol series, cleared in two changes of xylol, and sealed with Permount (Fisher). The cells were observed by phase contrast microscopy. An orange filter was used to increase the contrast of the Feulgen positive chromatin. For the determination of the meiotic stages, 300 cells were tabulated from each sample. For simplicity, anaphase I - telophase I, as well as anaphase II - telophase II were tabulated as single classes. The four nuclear stage and four spore stage were also tabulated together as a single class.

\subsection{Determination of glucose}

The glucose concentration in presporulation medium during vegetative growth was determined by the single reagent system based on hexokinase and glucose-6-phosphate dehydrogenase (Sigma Kit No. 15-10). Samples of $1 \mathrm{ml}$ were taken from the presporulation cultures, the cells were pelleted by centrifugation, and the glucose concentration in the supernatant medium determined after appropiate dilution with distilled water.

\subsection{Commitment to meiosis}

The time of commitment to meiosis was determined by transferring cells, which had been in sporulation medium for various lengths of time back to presporulation medium at a cell density of $2.5 \times 10^{8}$ cells. $\mathrm{ml}^{-1}$, where they were allowed to grow $14 \mathrm{~h}$ at $25^{\circ} \mathrm{C}$. The cultures were then analyzed after Feulgen staining.

\subsection{Segreation of ade 2}

The time of segregation of the ade2 marker of strain 11D was determined by plating samples from the sporulation culture on YPD agar at various times. The plates were incubated at $30^{\circ} \mathrm{C}$ for 6-7 days and the percentage of red plus red sectored colonies was determined by counting.

\subsection{DNA synthesis}

Premeiotic DNA synthesis was monitored by the incorporation of $\left[{ }^{3} \mathrm{H}\right]$ uracil into the alkaline resistant, TCA-precipitable fraction. [6${ }^{3} \mathrm{H}$ ]uracil (The Radiochemical Centre Amersham) was added at time $0 \mathrm{~h}\left(10 \mu \mathrm{Ci} \cdot \mathrm{ml}^{-1}\right)$ and duplicate $1.0 \mathrm{ml}$ samples were taken at intervals. The cells were washed twice in distilled water and resuspended in $1.0 \mathrm{ml}$ of uracil $(100$ $\mu \mathrm{g} \cdot \mathrm{ml}^{-1}$ ). Then $1.0 \mathrm{ml}$ of $1.0 \mathrm{~N}$ sodium hydroxide was added, and the suspension incubated for $24 \mathrm{~h}$ at $30^{\circ} \mathrm{C}$. The samples were neutralized with $1.0 \mathrm{ml}$ of $1.0 \mathrm{~N}$ hydrochloric acid and precipitated with $1.0 \mathrm{ml}$ of $40 \% \quad(\mathrm{w} / \mathrm{v})$ trichloroacetic acid (TCA) at $2-4^{\circ} \mathrm{C}$ for $2-3 \mathrm{~h}$. The precipitates were collected on glassfiber filters (Schleicher and Schuell Inc.) and 
wastred, first with $10 \mathrm{ml}$ cold $5 \%$ TCA, then 5 times with $3 \mathrm{ml}$ of cold $0.02 \mathrm{M}$ potassium phosphate buffer $\mathrm{pH}$ 6.5. The filters were dried at $65^{\circ} \mathrm{C}$ overnight, and counted in $5 \mathrm{ml}$ of $0.4 \%$ $(w / v)$ Omnifluor (New England Nuclear) in toluene using a Beckman Scintillation Counter, model LS 31557.

\subsection{RNA synthesis}

RNA synthesis was measured by the incorporation of $\left[{ }^{3} \mathrm{H}\right]$ uracil into cold TCAprecipitable material during 30 min pulses at various stages of sporulation $(12,16)$. At one hour intervals duplicate $0.1 \mathrm{ml}$ samples of sporulating culture were withdrawn. The cells were pelleted and resuspended in $0.1 \mathrm{ml}$ of a modified sporulation medium consisting of $1 \%$ $(w / v)$ potassium acetate, $0.05 \%(w / v)$ glucose, $\mathrm{pH} 6.0$ with $\left[{ }^{3} \mathrm{H}\right]$ uracil $\left(10 \mu \mathrm{Ci} \cdot \mathrm{ml}^{-1}, 500\right.$ $\left.\mu \mathrm{Ci} \cdot \mathrm{umol}^{-1}\right)$. Incorporation was allowed for 30 min at $25^{\circ} \mathrm{C}$ with aeration. Then $1.0 \mathrm{ml}$ of cold $10 \%(w / v)$ TCA supplemented with uracil (1 $\mathrm{mg} \cdot \mathrm{ml}^{-1}$ ) was added and the samples left on ice for $2-3 \mathrm{~h}$. The samples were then filtered onto glassfiber filters, washed 5 times with $5 \mathrm{ml}$ of cold 5\%(w/v) TCA, dried, and counted as described above. This procedure measures the sum of RNA and DNA synthesis, but the contribution of the latter is negligible, since the amount of DNA in yeast is small.

\section{RESULTS}

In Fig. 1 is shown the time course of meiosis and ascospore formation in a synchronized culture of strain 11D. Meiotic stages and synchrony of meiosis were determined by a modified Feulgen technique. At time 0 hour, approx. $70 \%$ of the cells have nuclei which are uniformly stained, and $30 \%$ of the nuclei exhibit some degree of chromosome individualization. In later samples the percentage of nuclei with individualized chromosomes increases. It is interpreted that these cells are in meiotic prophase or metaphase I. The maximum number of cells with individualized chromosomes approx. $65 \%$, is obtained at 8 hours in sporulation medium. With the staining technique described here it has not been possible to differentiate the stages of meiotic prophase with light microscopy. The first anaphase I telophase I cells are detected after $4 \mathrm{~h}$, with the maximum number at $10 \mathrm{~h}$. The first anaphase II - telophase II cells can be seen at approximately $8 \mathrm{~h}$, and the maximum number of cells observed in this stage occurs at $14 \mathrm{~h}$. Ascospore formation begins between 10 and $12 \mathrm{~h}$, and is essentially completed by $16 \mathrm{~h}$.

In Fig. 2(a-i) are shown photomicrographs of the various stages of meiosis and ascospore formation. The Feulgen positive chromatin appears dark, while the Feulgen negative nucleolus and reserve material appear lighter. The nucleus shown in Fig. 2(a) is typical for stationary growth phase cells and the early stages of meiosis. In Fig. 2(b-e) are shown individualized chromosomes. Fig. 2(d) and Fig. 2(e) are polar and planar views of metaphase I, respectively. Fig. 2(f-i) are of anaphase I telophase I, prophase II, anaphase II telophase II, and a tetrad of spores.

In the development of the synchronization technique used here two points were found to be of critical importance for the initiation of meiosis and the synchrony of the meiotic process, namely the length of time in which cells remained in the stationary growth phase, prior to shifting the cells to sporulation

Figure 1. Synchronous meiosis and ascospore formation of strain $11 \mathrm{D}$. The frequency distributions of the meiotic stages as observed by Feulgen staining and light microscopy are shown. 300 cells were scored per sample taken at various times after induction of meiosis by the transfer of stationary growth phase cells to SPO sporulation medium. Cell density $2.5 \times 10^{s}$ cells-ml-1, $25^{\circ} \mathrm{C}$. ( $(\star)$ Stage with uniformly distributed chromatin, corresponding to Fig. 2(a). (O-O) Apparent individualization of chromosomes, corresponding to Fig. 2(b-e). ( $\triangle-\Delta)$ Anaphase I - telophase I, corresponding to Fig. 2(f). ( $\nabla-\nabla)$ Anaphase II - telophase II, corresponding to Fig. 2(h). (- $\bullet$ ) Tetrad with four spores (and the tetranucleate stage), corresponding to Fig. 2(i). 
J. G. L. Petersen et al.: Sporulation of yeast

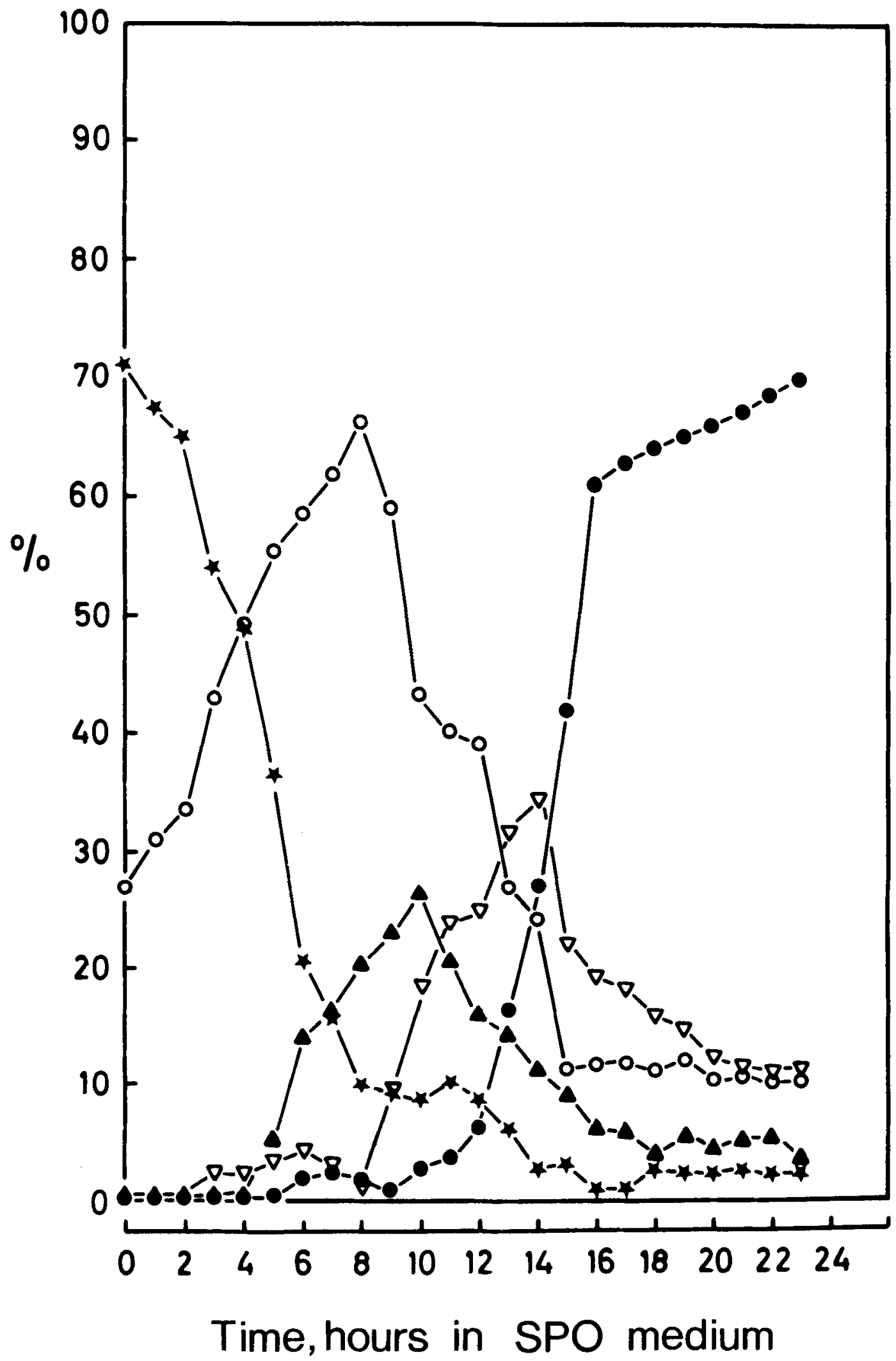



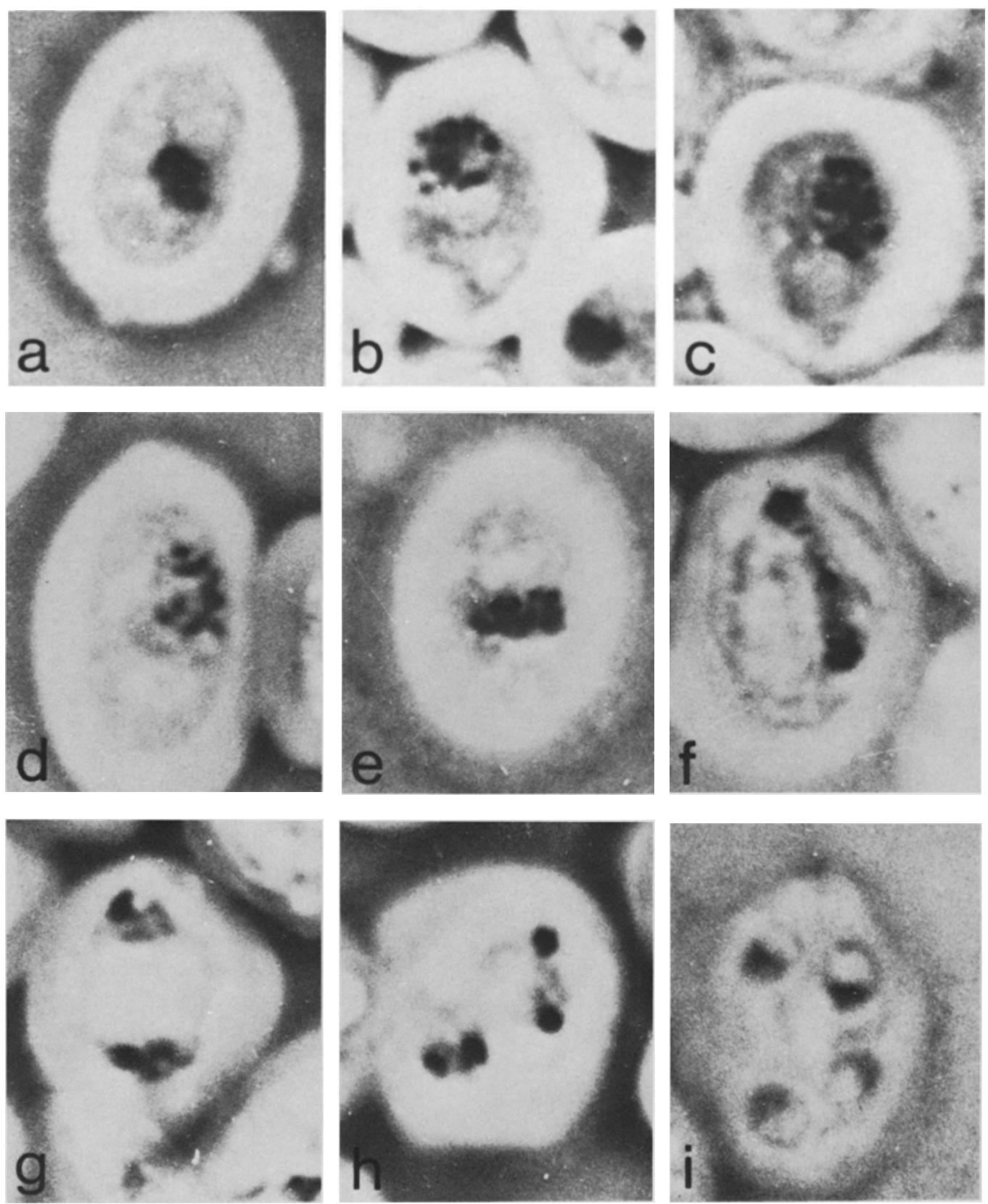

Figure 2. Various stages of meiosis as observed by light microscopy. The cells were fixed in Schaudinn's fixative, hydrolyzed and stained with p-Rosaniline-Schiffs reagent and photographed with phase contrast. (a) The nucleus is uniformely stained. This is characteristic for stationary growth phase cells and cells early after transfer to sporulation medium. The Feulgen positive material appears black on a grey background. (b)-(e) Individualization of chromosomes is observed at early times after transfer to sporulation medium. The Feulgen negative nucleolus in (b) is seen surrounded by the Feulgen positive chromatin. (d) and (e) Polar and planar views of metaphase I, respectively. (f) Anaphase I - telophase I. (g) Prophase II. (h) Anaphase II - telophase II. (i) Tetrad with spores. Magnification 5,600x. 


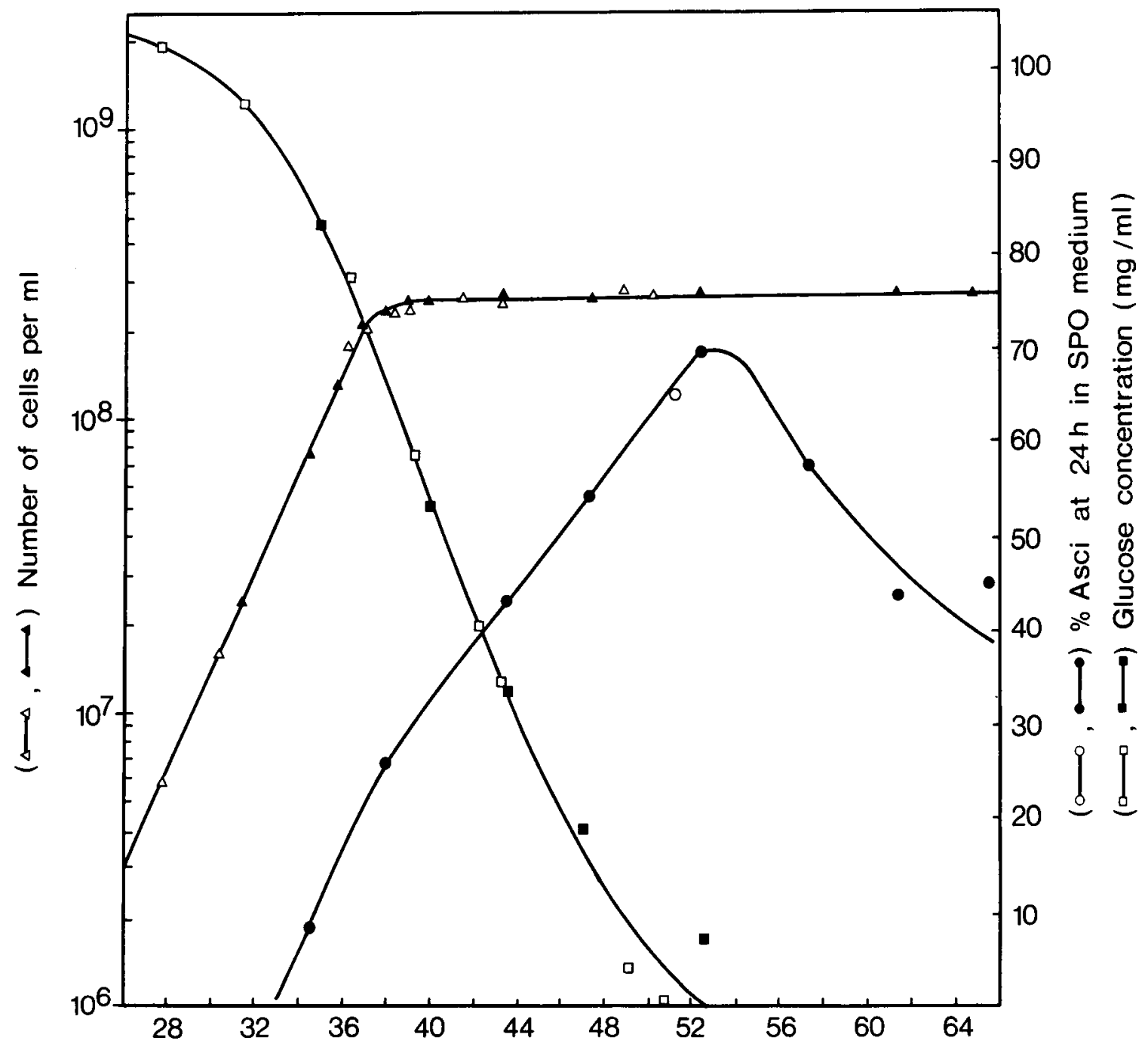

Time, hours in presporulation medium

Figure 3. The effiency of sporulation in relation to cell growth and the concentration of glucose in presporulation medium. A $100 \mathrm{ml}$ presporulation culture was started at time 0 by the inoculation $10^{2}-10^{3}$ cells $\cdot \mathrm{ml}^{-1}\left(25^{\circ} \mathrm{C}\right)$. Cell growth was followed by haemocytometer counts of $300-500$ cells, one bud counting as a single cell. Glucose was determined at various times after pelleting the cells by centrifugation. At various times cell samples of $1.25 \times 10^{9}$ cells were harvested, washed in SPO medium and resuspended in $4.8 \mathrm{ml}$ of SPO medium to give a final cell concentration of $2.5 \times 10^{8}$ cells $\cdot \mathrm{ml}^{-1}$, and allowed to sporulate for 24 hours, at which time the percentage of asci was determined by light microscopy. Left ordinate: $(\Delta-\Delta,(\Lambda-\Delta)$ Number of cells $\mathrm{ml}^{-1}(\log$ scale). Right ordinate: $(0-0,-\bullet)$ Percentage of asci formed after 24 hours in sporulation

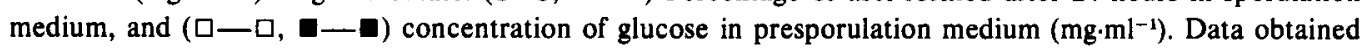
from two independent experiments, open and filled symbols, respectively. 


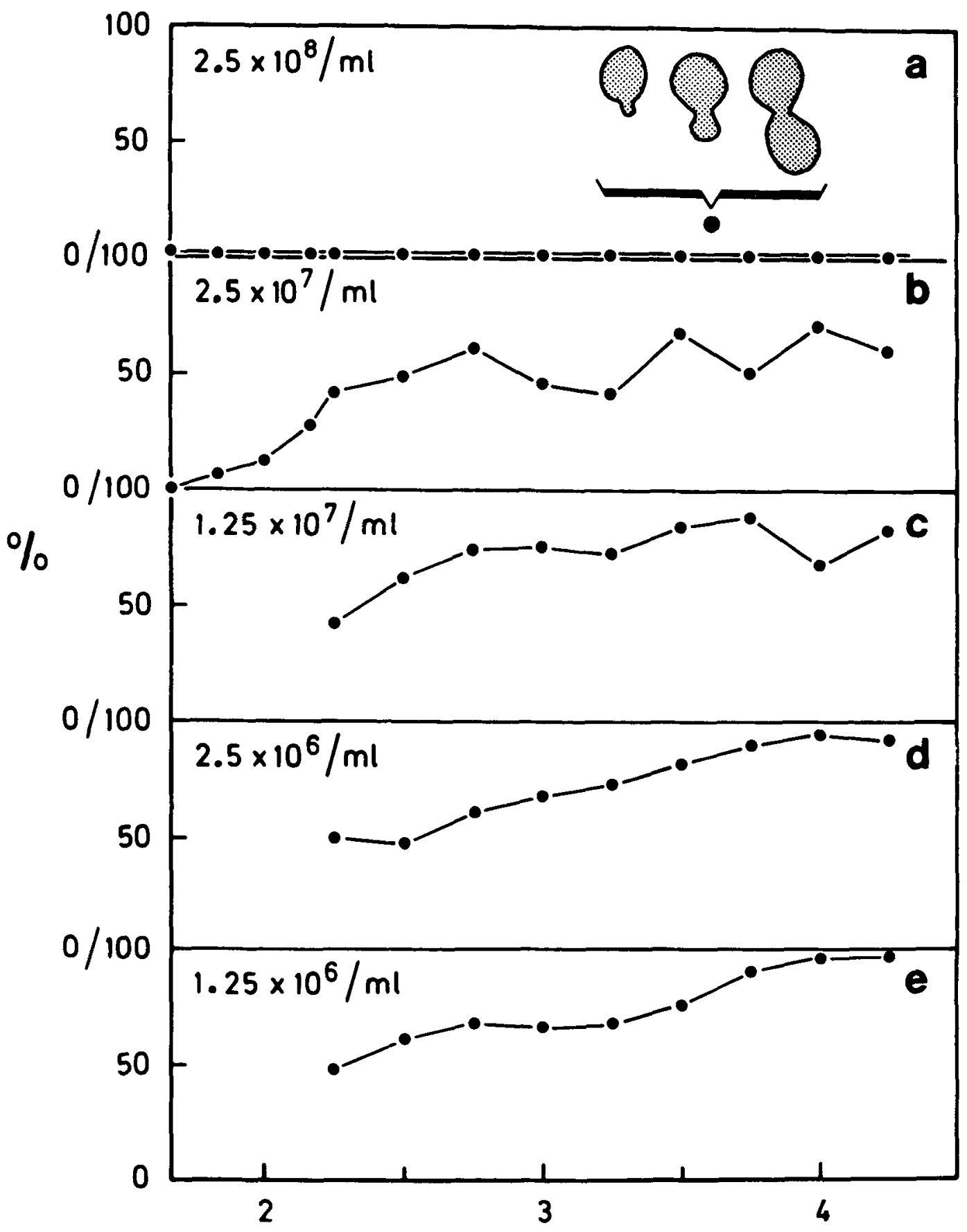

\section{Time, hours in SPO medium}

Figure 4. The effect of cell concentration on the induction of meiosis. Ordinate: Percentage of cells with buds. (a) When stationary cells are transferred to sporulation medium at a concentration of $2.5 \times 10^{8} \mathrm{cells}^{\mathrm{m}} \mathrm{ml}^{-1}$ budding is inhibited and the time course of meiosis shown in Figure 1 is obtained. (b)-(e) At lower cell concentrations a mitotic-budding cycle takes place. 300 cells were scored per sample. 
medium, and the cell density in the sporulation medium.

Fig. 3 shows the percentage of asci formed after $24 \mathrm{~h}$ in sporulation medium as a function of the length of time in which the cells were maintained in presporulation medium. Optimal formation of asci (65-70\%) was obtained with cells which had been in presporulation medium for $50-54 \mathrm{~h}$, corresponding to $10-14 \mathrm{~h}$ in the stationary phase. Also shown in Fig. 3 is the glucose concentration in presporulation medium during vegetative growth. It is seen that optimal sporulation is obtained with cells which are harvested close to the time when glucose is exhausted from the presporulation medium. At the time when the culture enters stationary phase at a cell concentration of approximately $2.6 \times 10^{8}$ cells $\cdot \mathrm{ml}^{-1}$ the glucose concentration is $6-7 \%(w / v)$. The limiting factor which causes the cells to enter stationary phase is therefore something else than the carbon source. During the first $10-14 \mathrm{~h}$ in stationary phase the cells actively ferment glucose. During this period buds become separated from their mother cells, the cells grow somewhat in size and get a granular appearance in phase contrast microscopy.

Optimal synchrony of meiosis was obtained at a cell density of $2.5 \times 10^{8}$ cells $\cdot \mathrm{ml}^{-1}$ in sporulation medium. Too high a cell concentration was found to totally block the initiation of meiosis, while too low a cell concentration resulted in cultures which would undergo one or several budding-mitotic cycles before entering meiosis, which is illustrated in Fig. 4.

Meiosis and ascospore formation are characterized by several major genetical and biochemical events. In this study we have determined the time of commitment to meiosis ( 7 , 20 ), the segregation of the recessive marker ade2 (19), and the time of DNA and RNA synthesis. The determination of these events and their correlation with the cytological changes are important as a basis for detailed biochemical studies. In addition, they give further information on the synchrony of the sporulation process.

Commitment to meiosis is defined as the stage where cells will continue to sporulate when transferred back to vegetative growth medium (7). In Fig. 5 is shown the fate of cells

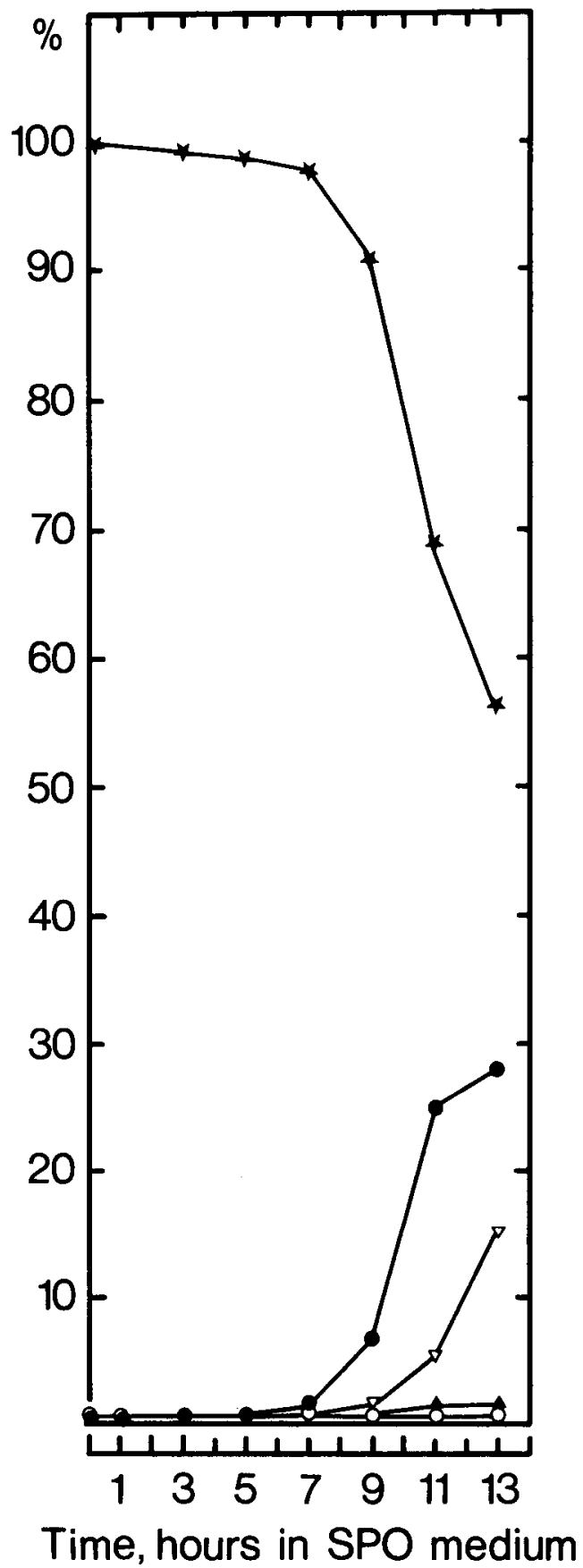

Figure 5. Determination of the time of commitment to meiosis. Cells were returned from sporulation medium at various times to presporulation medium at a concentration of $2.5 \times 10^{8}$ cells.ml $\mathrm{ml}^{-1}$, and analyzed at time 14 hours by Feulgen staining. ( $\star-\star$ ) Uniformly distributed chromatin. $(\mathrm{O}-\mathrm{O})$ Individualized chromosomes. (A-A) Anaphase I - telophase I. $(\nabla-\nabla)$ Anaphase II - telophase II. (-) The 4spore stage. 


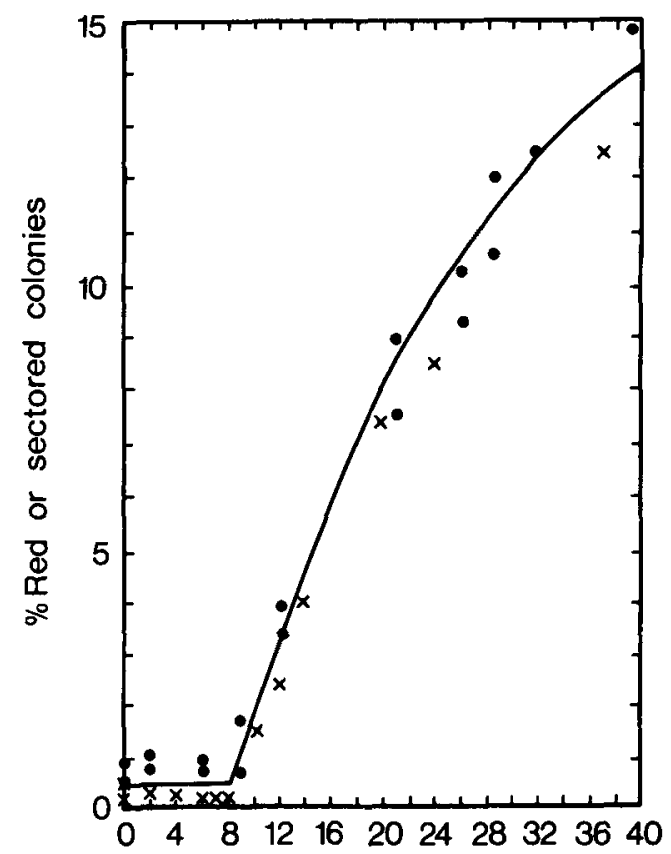

Time, hours in SPO medium

Figure 6. Determination of the time of segregation of ade2. The number of red or red sectored colonies formed on YPD agar 6-7 days after spreading of approx. 1000 cells at various times during sporulation. Data from two independent experiments.

transferred from sporulation medium to presporulation medium. It is seen, that until 7-8 $h$ in SPO medium the cells are capable of reverting to a mitotic-budding cycle, while an increasing number of cells from later samples become committed to spore formation. When this result is compared with the cytological data (Fig. 1), it is found that the time of commitment to meiosis is slightly earlier than the appearance of the first cells in the second meiotic division. Therefore, the stages of meiotic prophase do not seem to commit the cell to a sporulative development.

The time of segregation of the ade 2 marker, for which strain 11D is heterozygous, was determined by counting the number of red and red sectored colonies which arose on YPD agar after spreading of cell samples taken from sporulating cultures at various times. Red or red sectored colonies will form as a result of genetic recombination in diploid clones or by haploid segregation. Thus, segregation of ade 2 expresses the time of commitment to recombination. In Fig. 6 it is seen to occur from 7-9 h in SPO medium. In these experiments we have not been able to distinquish the time of commitment to recombination and the time of commitment to meiosis.

Fig. 7 shows the time course of DNA and RNA synthesis as determined by the incorporation of tritiated uracil. DNA synthesis (Fig. 7(a)) takes place from time $0 \mathrm{~h}$ and seems to be essentially completed after 8-9 $\mathrm{h}$. The DNA synthesis curve is not a true reflection of meiotic DNA replication, since mitochondrial DNA is also synthesized at the early stages of meiosis and is preferentially labelled (15). There seems to be some incorporation of isotope into DNA even after 8-9 $\mathrm{h}$. This probably is caused by the asynchrony of
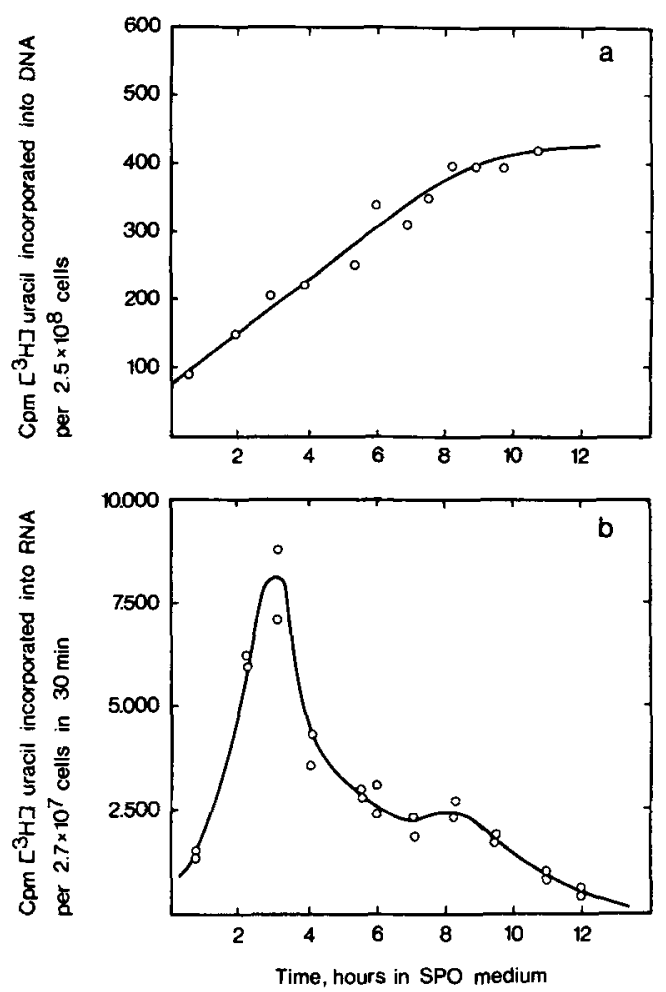

Figure 7. (a) DNA synthesis, and (b) RNA synthesis during sporulation of strain 11D monitored by the incorporation of $\left[{ }^{3} \mathrm{H}\right]$ uracil. For experimental details, see sections 2.8 , and 2.9 ., respectively. 
sporulation. RNA synthesis (Fig. 7(b)) increases rapidly from time $0 \mathrm{~h}$, reaching a maximum at 3 h. From $4 \mathrm{~h}$ to approximately $9 \mathrm{~h}$ RNA synthesis activity seems rather constant at levels one third of the maximum level.

\section{DISCUSSION}

The synchronization system described here, which employs pregrowth to stationary phase on glucose medium, is of a synchrony and rapidity comparable to systems using acetate pregrowth $(9,17,20)$. An important feature of the present sporulation procedure is the high cell concentration during sporulation, about 10 20 times higher than used in most other synchronization systems. The high cell concentration is advantageous in biochemical studies of meiosis, as it allows economical labelling of macromolecules with radioisotopes at high specific activities, and may facilitate the identification and isolation of compounds essential to meiosis, e.g. possible meiosis specific proteins and ribonucleic acids.

The presence of yeast extract $(0.1 \%(\mathrm{w} / \mathrm{v}))$ and glucose $(0.05 \%(\mathrm{w} / \mathrm{v}))$ in the sporulation medium is probably the reason why the correct cell concentration in the sporulation medium is of critical importance for the induction and synchrony of the sporulation cycle. Too low a cell concentration permits a budding-mitotic cycle to be initiated. The cells utilize the nitrogen source for growth and after its exhaustion are induced to enter meiosis. It is not clear why too high a cell concentration strongly represses the induction of sporulation. The importance of cell density for sporulation has also been noted by others (cf. 6).

The sporulation procedure was found to give good meiotic synchrony at high cell concentrations with several other diploid strains, while other strains sporulated poorly. Probably, optimal cell concentration is strain dependent. But also other factors are important in obtaining good synchrony, e.g. the time at which stationary cells are shifted to sporulation medium.

Croes (3) found that cells pregrown on complete medium containing glucose $(2 \%(w / v))$ began aerobic respiratory adaptation at the end of exponential growth. The change from fermentation to respiration occurred when glucose had disappeared from the growth medium. The cells now adapted themselves to ethanol utilization and thereby gained the ability to metabolize acetate, an important factor in the preparation of the cells to initiate meiosis. The highest sporulation frequencies were obtained with cell cultures which were shifted to sporulation medium approximately 3 $h$ after glucose was exhausted from the presporulation medium.

The data obtained with this presporulation procedure supports CROES' observations (Fig. 3 ). It was found that sporulation was optimal when the cells were shifted close to the time of exhaustion of glucose. This, however, did not occur until after 10-14 $\mathrm{h}$ in stationary phase because of the high initial concentration of glucose in our presporulation medium $(10 \%(w /$ v)).

The Feulgen staining technique described here has proven valuable in determining the meiotic stages and the synchrony of meiosis in yeasts. The method has been found to stain the nuclei of both vegetative and sporulating yeast cells more intensely and with greater detail than other Feulgen or Giemsa staining methods.

During sporulation of strain 11D the staining method identifies a stage with individualized chromosomes which is interpreted as meiotic prophase or metaphase I, maximum being at $8 \mathrm{~h}$ in SPO medium. However, even with the increased staining intensity of this technique, it is still not possible to differentiate the stages of the meiotic prophase.

ZICKLER and OLSON (23) studied synaptonemal complex formation during sporulation of strain 11D (mistakenly thought to be the original tetraploid strain 11) using the sporulation system described here. They found that at time 0 a few cells (3\%) showed short stretches of synaptonemal complexes. Less than $10 \%$ of the cells had long stretches of synaptonemal complexes during the first two hours in sporulation medium. From $2-4 \mathrm{~h}$ the majority of cells were in zygotene. From 4-6 h a large number of cells were in pachytene. At 6-8 h most cells were in diplotene. These fine structural observations of the meiotic prophase are 
in agreement with the light microscopic observations of the present study, which show an increasing number of cells with individualized chromosomes from 0 to $8 \mathrm{~h}$.

The rather precise determination of the meiotic stages that was obtained by Feulgen staining prompted us to correlate the sporulative development with some major events which characterize yeast sporulation. Studies of these events would also provide additional information on the synchrony of meiosis.

DNA synthesis during sporulation of strain $11 \mathrm{D}$ seems to take place essentially from 0 to 8 9 h (Fig. 7(a)). Allowing for the asynchrony in the cell culture many cells must have completed meiotic DNA replication at 7-8 h, which is the time when the first cells become committed to meiosis and spore formation (Fig. 5) and about the time when the first cells in anaphase II - telophase II are observed (Fig. 1). Thus, DNA replication, the meiotic prophase and perhaps the first meiotic division do not fully commit the cell to meiosis and spore formation. SIMCHEN et al. (20) and EsPOSITO and EsPOsito (4) found commitment to meiosis to occur slightly earlier than anaphase of the first meiotic division, i.e. earlier in the sporulation process than it was found in our studies.

The time of segregation of ade 2 occurred at approximately $8 \mathrm{~h}$ in sporulation medium (Fig. 6), close to the time when the first cells entered second meiotic division. SHERMAN and ROMAN (19) found the segregation of recessive markers to occur concomitantly with the appearance of binucleate cells, i.e. at an earlier stage than found in the present study. In the studies by EsPosito and EsPOSITo (4) commitment to intergenic as well as intragenic recombination at meiotic levels preceded commitment to meiosis and the appearance of anaphase I cells. We have not observed this separation of events. Since most of our experiments were done on separate cultures, variations from culture to culture may offer the simplest explanation why a finer separation of events has not been observed. This could also explain why we have found both commitment and segregation of a recessive marker to occur late in the sporulative development compared to some other studies.
DNA synthesis was found to take place between 0 and 8-9 h. Active RNA synthesis (Fig. 7(b)) and protein synthesis (14) also occurs within this period. The major portion of macromolecule synthesis thus appears to occur during meiotic prophase, in good agreement with other studies $(5,9,18)$. However, one should be careful when interpreting incorporation experiments, as changes in permeability, and the effect of $\mathrm{pH}$ during sporulation, may affect the measurements of synthetic activities (12). The recent finding that sporulation of yeast can be performed in buffered media (11) may overcome some of the difficulties encountered in incorporation studies.

In summary, the present study shows that sporulation of yeast can be induced at high cell concentrations. The synchrony and kinetics of meiosis and ascospore formation, as judged by Feulgen staining, and inferred from some characteristic biochemical and genetical events of sporulation, is similar to that of other sporulation procedures.

\section{ACKNOWLEDGEMENTS}

The authors wish to thank M. C. KIELLANDBRANDT and T. NILSSON-TILLGREN for many discussions and for critically reading the manuscript, and J. HANSEN for expert technical assistance.

\section{REFERENCES}

1. Bryant, T. R. and H. L. Howard: Meiosis in the Oomycetes: I. A microspectrophotometric analysis of nuclear deoxyribonucleic acid in Saprolegnia terrestris. Amer. J. Bot. 56, 10751083 (1969)

2. Croes, A. F.: Induction of meiosis in yeast. I. Timing of cytological and biochemical events. Planta (Berl.) 76, 209-226 (1967)

3. CRoEs, A. F.: Induction of meiosis in yeast. II. Metabolic factors leading to meiosis. Planta (Berl.) 76, 227-237 (1967) 
4. Esposito, R. E. and M. S. Esposito: Genetic recombination and commitment to meiosis in Saccharomyces. Proc. Nat. Acad. Sci. USA. 71, 3172-3176 (1974)

5. Esposito, M. S., R. E. Esposito, M. Arnaud and H. O. Halvorson: Acetate utilization and macromolecular synthesis during sporulation of yeast. J. Bact. 100, 180-186 (1969)

6. FowELL, R. R.: Sporulation and hybridization of yeasts. In "The yeasts", A. H. Rose and J. S. Harrison, eds., Academic Press, London and New York. Vol. I, pp 303-383 (1969)

7. Ganesan, A. T., H. Holter and C. Roberts: Some observations on sporulation in Saccharomyces. Compt. Rend. Lab. Carlsberg 31, 1 . 6 (1958)

8. Haber, J. E. and H. O. Halvorson: Regulation of sporulation in yeast. Current Topics in Develop. Biol. 7, 61-83 (1972)

9. Hopper, A. K., P. T. Magee, S. K. Welch, M. FRIEdman and B. D. HALL: Macromolecule synthesis and breakdown in relation to sporulation and meiosis in yeast. J. Bact. 119, 619-628 (1974)

10. McClary, D. O. W., W. L. Nulty and G. R. MILLER: Effect of potassium versus sodium in the sporulation of Saccharomyces. J. Bact. 78, 362368 (1959)

11. MCCUSKer, J. H. and J. E. HABer: Efficient sporulation of yeast in media buffered near $\mathrm{pH} 6$. J. Bact. 132, 180-187 (1977)

12. Mills, D.: Effect of $\mathrm{pH}$ on adenine and amino acid uptake during sporulation in Saccharomyces cerevisiae. J. Bact. 112, 519-526 (1972)

13. Olson, L. W. and M. S. Fuller: Leucine-lysine synchronization of Allomyces germlings. Arch. Mikrobiologie 78, 76-91 (1971)
14. Petersen, J. G. L., M. C. Kielland-Brandt and T. NiLSSON-Tillgren: Manuscript in preparation.

15. Pinon, R., Y. SALtS and G. SimCHEN: Nuclear and mitochondrial DNA synthesis during yeast sporulation. Exptl. Cell Res. 83, 231-238 (1974)

16. Rodengerg, S., W. Steinberg, J. Piper, K. Nickerson, J. VARY, R. EPSTeIN and H. O. HaLVorson: Relationship between protein and ribonucleic acid synthesis during outgrowth of spores of Bacillus cereus. J. Bact. 96, 492-500 (1968)

17. Roth, R. and H. O. Halvorson: Sporulation of yeast harvested during logarithmic growth. J. Bact. 98, 831-832 (1969)

18. SANDO, N. and S. MIYAKEE: Biochemical changes in yeast during sporulation. I. Fate of nucleic acids and related compounds. Development, Growth and Differentiation 12, 273-283 (1971)

19. Sherman, F. and H. Roman: Evidence for two types of allelic recombination in yeast. Genetics 48, 255-261 (1963)

20. Simchen, G., R. Pinon and Y. SAlts: Sporulation in Saccharomyces cerevisiae: Premeiotic DNA synthesis, readiness and commitment. Expt1. Cell Res. 75, 207-218 (1972)

21. Snustad, D. P. and D. S. Dean: Genetic experiments with bacterial viruses. W. W. Freeman and Co., San Francisco, pp. 1-65 (1971)

22. Tingle, M., A. J. S. Klar, S. A. Henry and H. O. HALVORSON: Ascospore formation in yeast. Symp. Soc. Gen. Microbiol. 23, 209-243 (1973)

23. ZICKLER, D. and L. W. OLson: The synaptonemal complex and the spindle plaque during meiosis in yeast. Chromosoma (Berl.) 50, 1-23 (1975) 